\title{
New Surface Aspects towards Photocatalytic Activity of Doped Supported Titanium Dioxide
}

\author{
Samia A. Kosa, ${ }^{1}$ Eman Z. Hegazy, ${ }^{1,2}$ Saleha S. Maashi, ${ }^{3}$ \\ Islam H. Abd El Maksod, ${ }^{1,2}$ and Laila M. Al-Harbi ${ }^{1}$ \\ ${ }^{1}$ King Abdulaziz University, P.O. Box 80203, Jeddah 21589, Saudi Arabia \\ ${ }^{2}$ National Research Centre, Dokki, Cairo, Egypt \\ ${ }^{3}$ Taif University, Taif, Saudi Arabia
}

Correspondence should be addressed to Samia A. Kosa; skousah@kau.edu.sa

Received 1 December 2015; Revised 6 February 2016; Accepted 14 February 2016

Academic Editor: Mohammad Muneer

Copyright (C) 2016 Samia A. Kosa et al. This is an open access article distributed under the Creative Commons Attribution License, which permits unrestricted use, distribution, and reproduction in any medium, provided the original work is properly cited.

\begin{abstract}
The present work aims to synthesize nanoscale well dispersed $\mathrm{TiO}_{2} / \mathrm{SiO}_{2}$ and $\mathrm{TiO}_{2} / \mathrm{Al}_{2} \mathrm{O}_{3}$ nanoparticle photocatalysts via an impregnation method for the removal of methyl orange, which was used as a model compound of organic pollutant in wastewater, from an aqueous medium. Also within this frame work, $\mathrm{La}$ and Ce metals were loaded onto the surfaces of $\mathrm{TiO}_{2} / \mathrm{SiO} 2$ and $\mathrm{TiO}_{2} / \mathrm{Al}_{2} \mathrm{O}_{3}$ by an impregnation method to enhance the photocatalytic activity of the nanoparticles; the activities and physicochemical properties of the photocatalysts were compared before and after loading of metallic La and Ce. The oxide system was characterized by different techniques, including XRD, UV-Vis spectroscopy, FT-IR spectroscopy, SEM, and EDX spectroscopy. Finally, the optimal conditions to complete the photocatalytic oxidation of methyl orange dye were studied. This work holds promise for the efficient photodegradation of pollutants by nanoparticle photocatalysts.
\end{abstract}

\section{Introduction}

Methyl orange is widely used as an acid-base indicator, and it has also been employed in chemical, technological, and biomedical industries. Its chemical properties have been widely investigated in aqueous solutions and in water and organic mixed solvents [1]. Additionally, this compound has been widely used in printing, paper, food, pharmaceutical, and textile industries, as well as research laboratories [2]. It is an orange-colored, anionic dye that possesses absorbance maximum at $464 \mathrm{~nm}$. Methyl orange is a compound that exists in textile wastewaters and has various harmful effects on humans. For example, it may cause eye or skin irritation, and inhalation may cause gastrointestinal irritation with nausea, vomiting, and diarrhea. There are various technological processes such as adsorption, biodegradation, chemical methods, electrocoagulation, electrochemical reduction and oxidation, indirect electrooxidation with strong oxidants, and photocatalytic degradation that can be used for the treatment of wastewaters, including those containing synthetic dyes
$[3,4]$. A number of studies have dealt with the heterogeneous photocatalytic decomposition of many types of azo dyes by UV, visible light, and solar irradiation. The dangerous accumulation of dyes in the environment can be avoided by developing effective ways for their removal either by the degradation of such organic pollutants to less harmful compounds [5] or by their complete mineralization [6], such as titanium dioxide, which has been widely used as a photocatalyst for the degradation of MO. The photocatalytic efficiency of a nanocrystalline $\mathrm{TiO}_{2}$ system is strongly influenced by light sources and the recombination of photoinduced electrons and holes. It is known that gold deposited onto $\mathrm{TiO}_{2}$ surface inhibits the recombination of photogenerated electrons and holes. The photocatalytic deposition of metals onto titanium dioxide films is one of the most interesting methods for producing titanium dioxide/metal composites. The pairing of $\mathrm{TiO}_{2}$ with other metals, including $\mathrm{Au}, \mathrm{Ti}, \mathrm{Ce}, \mathrm{Fe}$, and $\mathrm{Pt}$ [6], has been used to increase the activity of $\mathrm{TiO}_{2}$ towards the degradation of azo dyes, such as methyl orange. 
TABLE 1: Compositions of different $\mathrm{TiO}_{2} / \mathrm{SiO}_{2}$ samples.

\begin{tabular}{lcc}
\hline $\begin{array}{l}\text { Concentration of } \mathrm{TiO}_{2} \\
\text { (wt.\%) in } \mathrm{TiO}_{2} / \mathrm{SiO}_{2}\end{array}$ & Source of titanium & Support type \\
\hline 2.5 & & \\
5 & $\mathrm{TiCl}_{4}$ & \\
10 & & \\
20 & & $\mathrm{SiO}_{2}$ \\
2.5 & & \\
5 & TIP & \\
10 & & \\
20 & & \\
\hline
\end{tabular}

\section{Experimental}

2.1. Materials. All chemicals used in the preparation of $\mathrm{TiO}_{2} /$ $\mathrm{SiO}_{2}, \mathrm{TiO}_{2} / \mathrm{Al}_{2} \mathrm{O}_{3}, \mathrm{La}-\mathrm{TiO}_{2} / \mathrm{Al}_{2} \mathrm{O}_{3}$, and $\mathrm{Ce}-\mathrm{TiO}_{2} / \mathrm{Al}_{2} \mathrm{O}_{3}$ nanoparticles were analytical grade reagents. The following high purity raw materials were used:

(i) Titanium(IV) oxide, anatase, 325 mesh, $\geq 99 \%$ metals basis, $\mathrm{TiO}_{2}$, Sigma-Aldrich Laboratories Supplies [Canada].

(ii) Titanium(IV) isopropoxide, 98\%, $\mathrm{C}_{12} \mathrm{H}_{28} \mathrm{O}_{4} \mathrm{Ti}$, ACROS Organics.

(iii) Titanium tetrachloride, $\mathrm{TiCl}_{4}$, Fluka AG Laboratories Supplies.

(iv) Aluminum oxide, $\mathrm{Al}_{2} \mathrm{O}_{3}$, Fluka Laboratories Supplies [Switzerland].

(v) Silica precipitated, $\mathrm{SiO}_{2}, \mathrm{BDH}$ Laboratories Supplies [Poole, England].

(vi) Lanthanum(III) nitrate hexahydrate, $\mathrm{La}\left(\mathrm{NO}_{3}\right)_{3} \cdot 6 \mathrm{H}_{2} \mathrm{O}$, 99.999\%, ACROS Organics Laboratories Supplies [New Jersey, USA].

(vii) Ammonium cerium(IV) nitrate, 99\%, $\mathrm{H}_{8} \mathrm{CeN}_{8} \mathrm{O}_{18}$, ACROS Organics Laboratories Supplies [New Jersey, USA].

(viii) Methyl orange indicator, Pacegrove Limited Laboratories Supplies [UK].

2.2. Procedure and Apparatus. The loading of titanium tetra chloride $\left(\mathrm{TiCl}_{4}\right)$ or titanium isopropoxide (TIP) into silica $\left(\mathrm{SiO}_{2}\right)$ or aluminum oxide $\left(\mathrm{Al}_{2} \mathrm{O}_{3}\right)$ was performed by the impregnation method (Img).

2.2.1. Preparation of $\mathrm{TiO}_{2} / \mathrm{SiO}_{2}$. Five grams of silica was mixed with a certain amount of titanium isopropoxide (TIP) or titanium tetra chloride $\left(\mathrm{TiCl}_{4}\right)$. Then, a minimal amount of distilled water was added dropwise to the mixture, under vigorous stirring, to obtain $2.5,5,10$, and $20 \mathrm{wt} . \% \mathrm{TiO}_{2}$, as shown in Table 1 . The formed paste was completely mixed to obtain a homogeneous mixture, and it was then dried in an oven at $100^{\circ} \mathrm{C}$ for $24 \mathrm{~h}$. The resultant powder was ground using a mortar and pestle, followed by calcination at $550^{\circ} \mathrm{C}$ for $4 \mathrm{~h}$ in open air atmosphere.
TABLE 2: Compositions of different $\mathrm{TiO}_{2} / \mathrm{Al}_{2} \mathrm{O}_{3}$ samples.

\begin{tabular}{lcc}
\hline $\begin{array}{l}\text { Concentration of } \mathrm{TiO}_{2} \\
\text { (wt.\%) in } \mathrm{TiO}_{2} / \mathrm{Al}_{2} \mathrm{O}_{3}\end{array}$ & Source of titanium & Support type \\
\hline 2.5 & $\mathrm{TiCl}_{4}$ & \\
5 & & \\
10 & & \\
20 & & \\
2.5 & $\mathrm{Al} \mathrm{O}_{3}$ \\
5 & TIP & \\
10 & & \\
20 & & \\
\hline
\end{tabular}

TABle 3: Composition of different La-doped samples.

\begin{tabular}{lc}
\hline La: Ti mole ratio & wt.\% loading \\
\hline 0.05 & 5 \\
0.1 & \\
0.2 & \\
0.3 & \\
\hline
\end{tabular}

2.2.2. Preparation of $\mathrm{TiO}_{2} / \mathrm{Al}_{2} \mathrm{O}_{3}$. Five grams of aluminum oxide $\left(\mathrm{Al}_{2} \mathrm{O}_{3}\right)$ was mixed with a certain amount of titanium isopropoxide (TIP) or titanium tetra chloride $\left(\mathrm{TiCl}_{4}\right)$. Then, a minimal amount of distilled water was added dropwise to the mixture, under vigorous stirring, to obtain $2.5,5,10$, and 20 wt. $\% \mathrm{TiO}_{2}$, as shown in Table 2. The formed paste was completely mixed to obtain a homogeneous mixture, which was then dried in an oven at $100^{\circ} \mathrm{C}$ for $24 \mathrm{~h}$. The powder was ground using a mortar and pestle, followed by calcination at $550^{\circ} \mathrm{C}$ for $4 \mathrm{~h}$.

2.2.3. Preparation of $\mathrm{La}$ Metal Loaded $\mathrm{TiO}_{2} / \mathrm{Al}_{2} \mathrm{O}_{3}$. Lanthanum(III) nitrate hexahydrate, $\mathrm{La}\left(\mathrm{NO}_{3}\right)_{3} \cdot 6 \mathrm{H}_{2} \mathrm{O}$, was used as the source of the $\mathrm{La}$ (III) dopant. The detailed procedure for the preparation of 4 dopant concentrations $(0.05,0.1,0.2$, and 0.3 mole ratio of $\mathrm{La}$ to $\mathrm{Ti}$ ) by the impregnation method is as follows. An appropriate amount of $\mathrm{La}\left(\mathrm{NO}_{3}\right)_{3} \cdot 6 \mathrm{H}_{2} \mathrm{O}$ was dissolved in a small amount of distilled water. This solution was then added dropwise to $5 \mathrm{~g}$ of $\mathrm{TiO}_{2} / \mathrm{Al}_{2} \mathrm{O}_{3}\left(5 \mathrm{wt}\right.$. $\% \mathrm{TiO}_{2}$ ) with constant stirring, as shown in Table 3. The product was dried in an oven at $100^{\circ} \mathrm{C}$ for $24 \mathrm{~h}$ and was ground to a fine powder. Then, it was calcined at $550^{\circ} \mathrm{C}$ for $4 \mathrm{~h}$ in a muffle furnace.

2.2.4. Preparation of $\mathrm{Ce}$-Metal Loaded $\mathrm{TiO}_{2} / \mathrm{Al}_{2} \mathrm{O}_{3}$. Ammonium cerium(IV) nitrate, $\left(\mathrm{NH}_{4}\right)_{2} \mathrm{Ce}\left(\mathrm{NO}_{3}\right)_{6}$, was used as the source of the $\mathrm{Ce}(\mathrm{IV})$ dopant. The detailed procedure for the preparation of 4 dopant concentrations $(0.05,0.1,0.2$, and 0.3 mole ratio of $\mathrm{Ce}$ to $\mathrm{Ti}$ ) by the impregnation method is as follows. The appropriate amount of $\left(\mathrm{NH}_{4}\right)_{2} \mathrm{Ce}\left(\mathrm{NO}_{3}\right)_{6}$ was dissolved in a small amount of distilled water. This was then added dropwise to $5 \mathrm{~g}$ of $\mathrm{TiO}_{2} / \mathrm{Al}_{2} \mathrm{O}_{3}\left(5 \mathrm{wt} . \% \mathrm{TiO}_{2}\right.$ ) with constant stirring, as shown in Table 4 . The product was dried in an oven at $100^{\circ} \mathrm{C}$ for $24 \mathrm{~h}$ and was ground to fine powder. Then, it was calcined at $550^{\circ} \mathrm{C}$ for $4 \mathrm{~h}$ in a muffle furnace. 


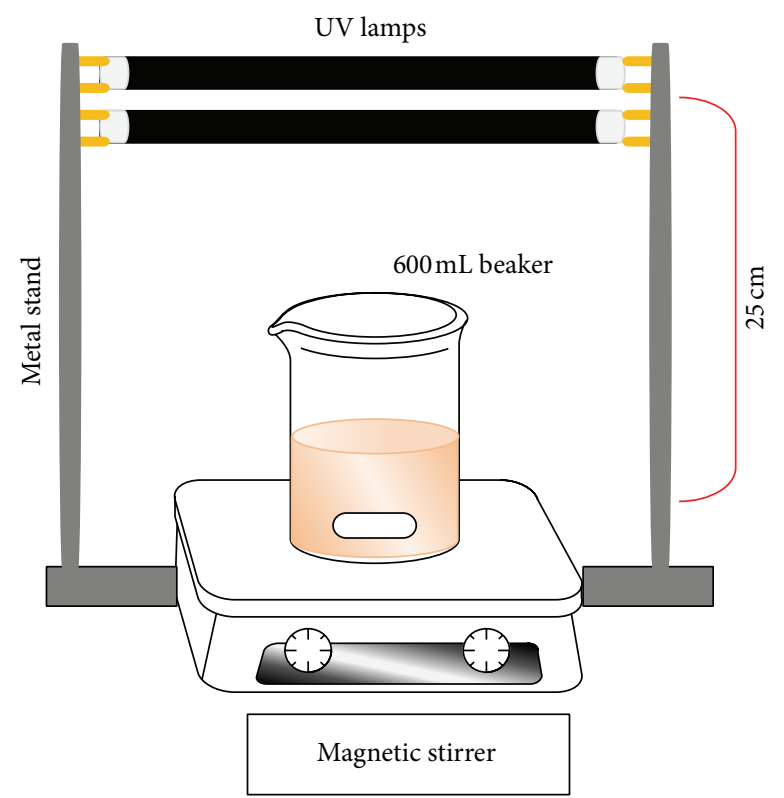

FIGURE 1: Experimental set-up for the photocatalytic reaction.

TABLE 4: Composition of different Ce-doped samples.

\begin{tabular}{lc}
\hline Ce: Ti mole ratio & wt.\% loading \\
\hline 0.05 & \\
0.1 & 5 \\
0.2 & \\
0.3 & \\
\hline
\end{tabular}

2.3. Characterization Techniques and Control Test. The synthesized samples were evaluated and characterized by determining photocatalytic activity, particle size, and phase using XRD, UV-Vis, FT-IR, SEM, and EDX. Experimental details are as follows.

2.3.1. X-Ray Powder Diffraction (XRD) Analysis. The crystalline phase and crystallite size of all catalyst nanoparticle samples were analyzed by X-ray powder diffraction (XRD) using a Rigaku X-ray diffractometer system equipped with a RINT 2000 wide angle Goniometer and $\mathrm{Cu} \mathrm{K} \alpha$ radiation $(\lambda=$ $0.15478 \mathrm{~nm}$ ) at a power of $40 \mathrm{kV} \times 30 \mathrm{~mA}$. The intensity data were collected at room temperature over a range of $2 \theta$ from 10 to $80^{\circ}$.

2.3.2. Ultraviolet-Visible (UV-Vis) Spectroscopy. The concentration of the dye was followed up using UV-Vis spectrophotometer (Thermo Fisher Scientific Evolution 300).

2.3.3. Fourier Transform Infrared (FT-IR) Spectroscopy. To study the surface chemical structures of all catalyst nanoparticle samples, Fourier transform infrared (FT-IR) spectra were recorded on a PerkinElmer FT-IR instrument 100 series.
2.3.4. Scanning Electron Microscopy (SEM) and Energy Dispersive X-Ray (EDX) Spectroscopy. Surface morphologies and shapes of all catalyst nanoparticle samples were examined via a field-emission scanning electron microscope (SEM), which was obtained using JEOL JSM-7600F. This system was combined with energy dispersive X-ray spectroscopy for composition and elemental analysis.

\subsection{Photocatalytic Degradation of Methyl Orange}

2.4.1. The Experiment for Photocatalytic Degradation of Methyl Orange. The photocatalytic activity of each prepared sample was evaluated by degradation of a pollutant in water. Methyl orange (MO), a common textile dye, was used as the model pollutant. The activity of the photocatalyst was tested by analyzing the decomposition of MO under UV irradiation. The MO solutions varied in concentration from 1 to $20 \mathrm{ppm}$ and were prepared by dissolving $\mathrm{MO}$ powder in distilled water: $250 \mathrm{~mL}$ of $1 \mathrm{ppm} \mathrm{MO}$ solution was added to a Pyrex beaker $(600 \mathrm{~mL})$ and $0.5 \mathrm{~g}$ of $\mathrm{TiO}_{2} / \mathrm{SiO}_{2}, \mathrm{TiO}_{2} / \mathrm{Al}_{2} \mathrm{O}_{3}$, La$\mathrm{TiO}_{2} / \mathrm{Al}_{2} \mathrm{O}_{3}$, or $\mathrm{Ce}-\mathrm{TiO}_{2} / \mathrm{Al}_{2} \mathrm{O}_{3}$ was added to the solution. The suspension was magnetically stirred in the dark for various time intervals. An $8 \mathrm{~W}$ Philip's lamp was used as the UV source at a fixed distance of $25 \mathrm{~cm}$ from the top of the magnetic stir bar. All components of the experimental setup were located inside a box, as shown in Figure 1. A $10 \mathrm{~mL}$ sample was taken from the beaker at various time intervals, and the photocatalyst was separated from the solution by filtration. Absorbance measurements were also recorded in the range of 200-600 nm using UV-Vis spectrophotometer.

The concentration of MO solutions was determined by measuring the absorbance at approximately $465 \mathrm{~nm}$ using UV-Vis spectrophotometer (Thermo Fisher Scientific Evolution 300 , USA). 


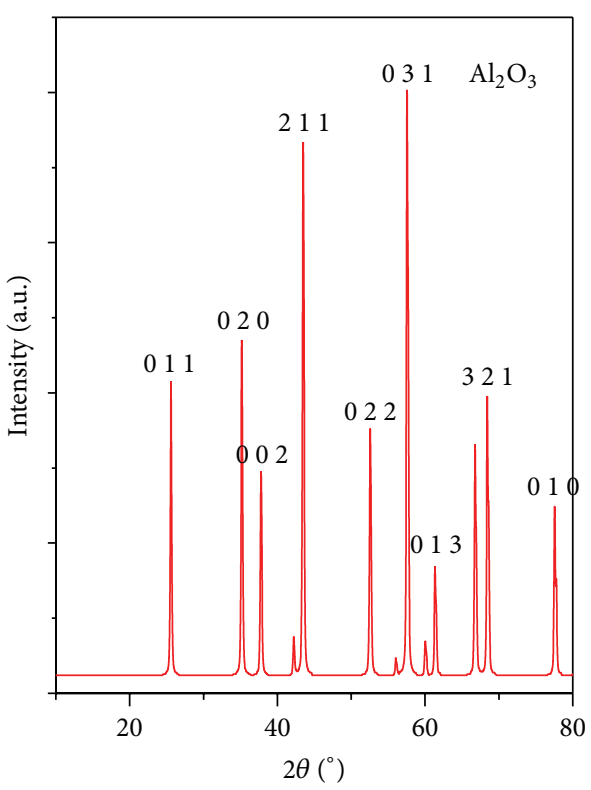

FIGURE 2: XRD pattern of $5 \mathrm{wt} . \% \mathrm{TiO}_{2} / \mathrm{Al}_{2} \mathrm{O}_{3}$ (using TIP as a source of $\mathrm{TiO}_{2}$ ) nominated with $h k l$ values of planes.

\section{Results and Discussion}

3.1. Characterization of Investigated Samples. For catalyst characterization, knowing the catalyst's texture and phase, as well as its chemical composition, represents an essential minimum. XRD, FT-IR, SEM, EDX, and UV-Vis are basic methods that provide the required information.

3.1.1. XRD Analysis. The XRD patterns of $5 \mathrm{wt}$ \% loaded samples on $\mathrm{Al}_{2} \mathrm{O}_{3}$ only showed the crystalline of corundum phase of the support; there was no indication of any crystalline phase of $\mathrm{TiO}_{2}$. This could be explained by the low detection limit of XRD towards $\mathrm{TiO}_{2}$ or by $\mathrm{TiO}_{2}$ being well dispersed over $\mathrm{Al}_{2} \mathrm{O}_{3}$ support (Figure 2) [7,8]. For high loading percent of $\mathrm{TiO}_{2}$ a small fraction of anatase form was detected (figures not given).

3.1.2. FT-IR Analysis. The FT-IR spectra of different doped and undoped samples are shown in Figures 3-6. The FT-IR spectra of solids were recorded before and after the reaction. The vibrational mode of $\mathrm{Ti}-\mathrm{O}$ and $\mathrm{Al}-\mathrm{O}$ was clearly observed in all samples.

Doping with $\mathrm{La}$ or $\mathrm{Ce}$ did not change the $\mathrm{Ti}-\mathrm{O}$ and $\mathrm{Al}-\mathrm{O}$ bands; however, after the reaction of most samples, a slight change in the positions and the shapes of these peaks was observed. This could be explained by a physical change of the support after reacting.

In Figure 6, it can be observed that the lower absorption bands (326 and $418 \mathrm{~cm}^{-1}$ ), which are assigned to the M$\mathrm{O}$ vibration $(\mathrm{M}=\mathrm{Ti}, \mathrm{La}$, or $\mathrm{Al})$ [9-12], are well separated in undoped samples; however, even with a doping level of 0.05 wt.\%, only unresolved bands are observed.

3.1.3. SEM Analysis of Samples. Figures 7-11 show SEM images of different loaded samples on top of $\mathrm{Al}_{2} \mathrm{O}_{3}$ support.

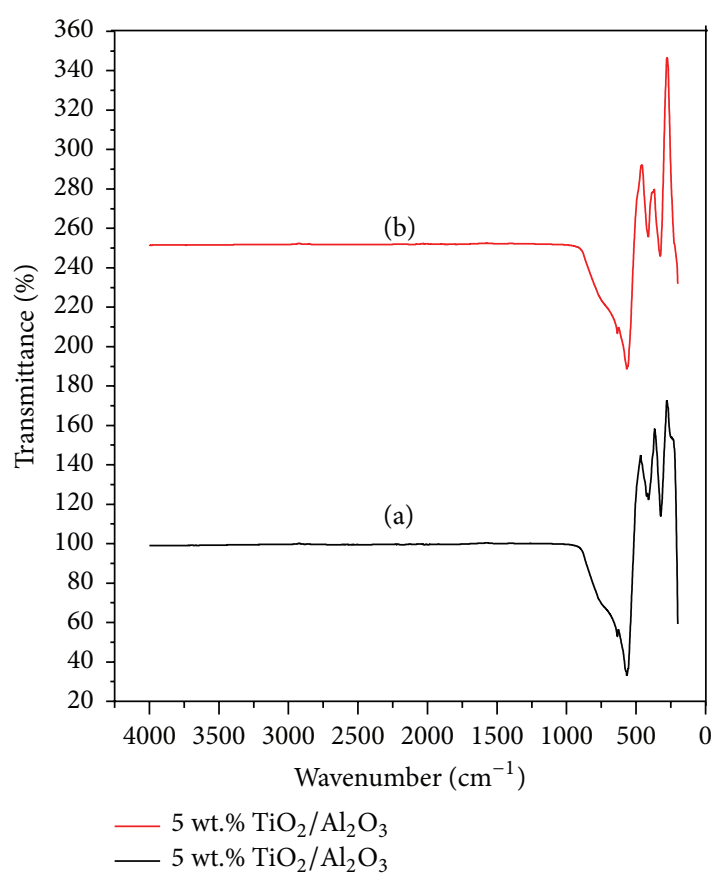

FIGURE 3: FT-IR spectra of 5 wt. $\% \mathrm{TiO}_{2} / \mathrm{Al}_{2} \mathrm{O}_{3}$ (a) before reaction and (b) after reaction (using TIP as a source of $\mathrm{TiO}_{2}$ ).

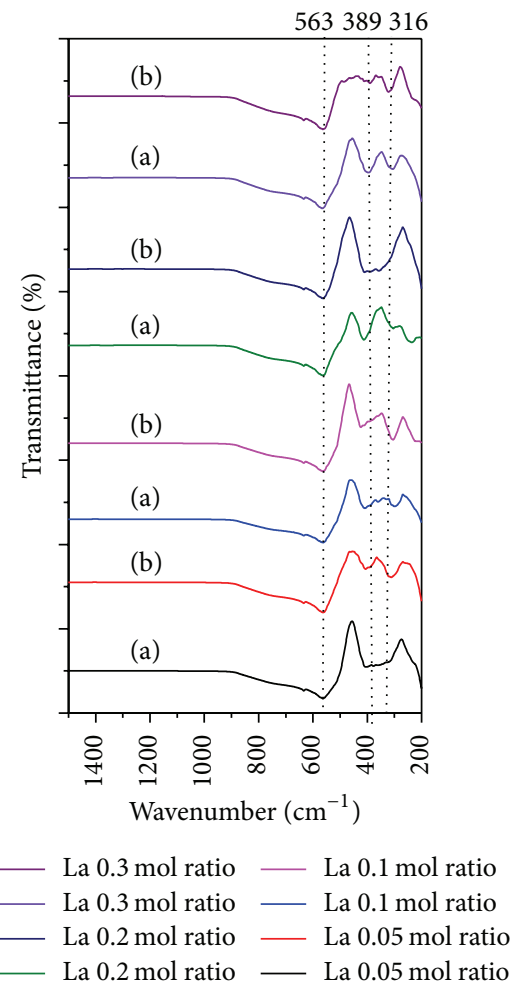

FIGURE 4: FT-IR spectra of $0.05,0.1,0.2$, and 0.3 mole ratio $\mathrm{La}_{-} \mathrm{TiO}_{2} /$ $\mathrm{Al}_{2} \mathrm{O}_{3}$ (a) before reaction and (b) after reaction.

The shape of $\mathrm{Al}_{2} \mathrm{O}_{3}$ support was clearly observed in all samples. No aggregations of $\mathrm{TiO}_{2}$ were observed, as expected from XRD, which leads to the conclusion that $\mathrm{TiO}_{2}$ is well 


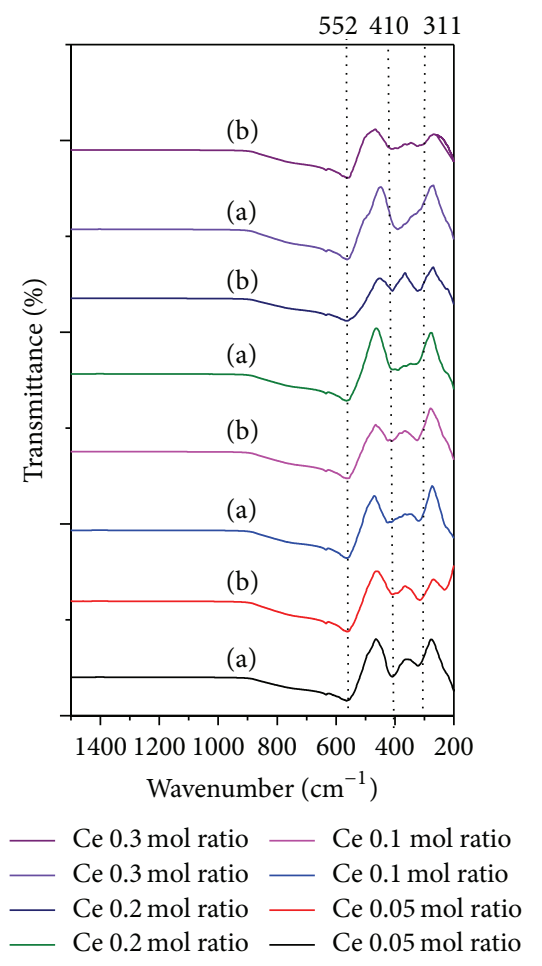

FIgURE 5: FT-IR spectra of $0.05,0.1,0.2$, and 0.3 mole ratio $\mathrm{Ce}-\mathrm{TiO}_{2} /$ $\mathrm{Al}_{2} \mathrm{O}_{3}$ (a) before reaction and (b) after reaction.

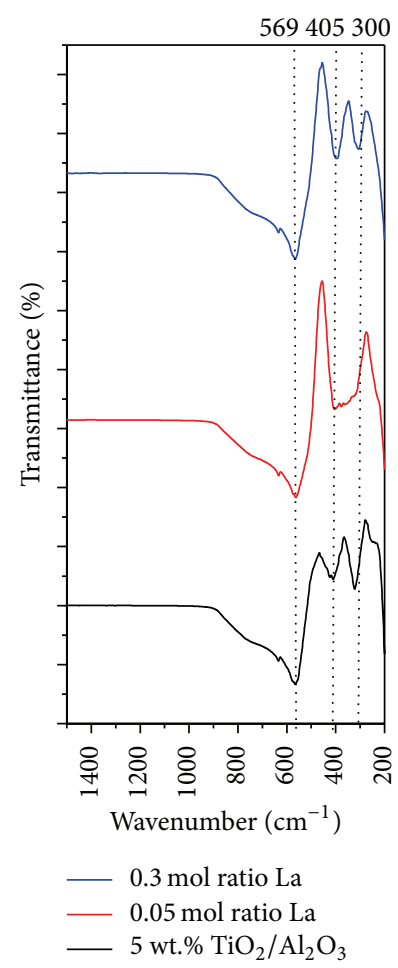

FIGURE 6: FT-IR spectra of La-doped and undoped samples.

dispersed over $\mathrm{Al}_{2} \mathrm{O}_{3}$ support and indicates its presence in nanoscale [13].

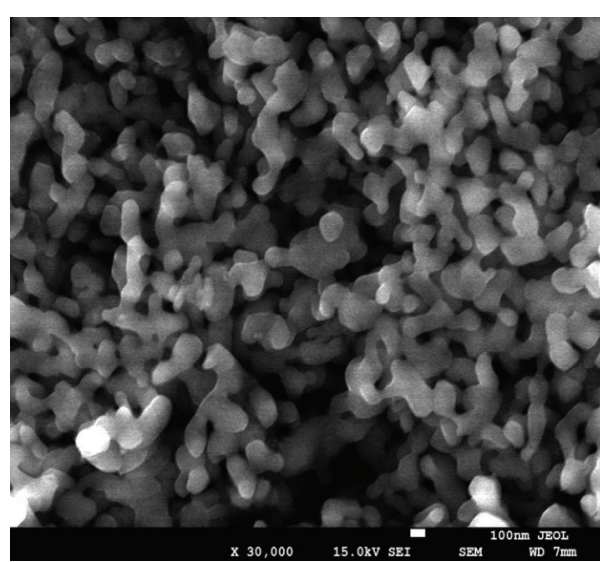

FIgURE 7: SEM image of 0.05 mole ratio La-loaded on $\mathrm{TiO}_{2} / \mathrm{Al}_{2} \mathrm{O}_{3}$.

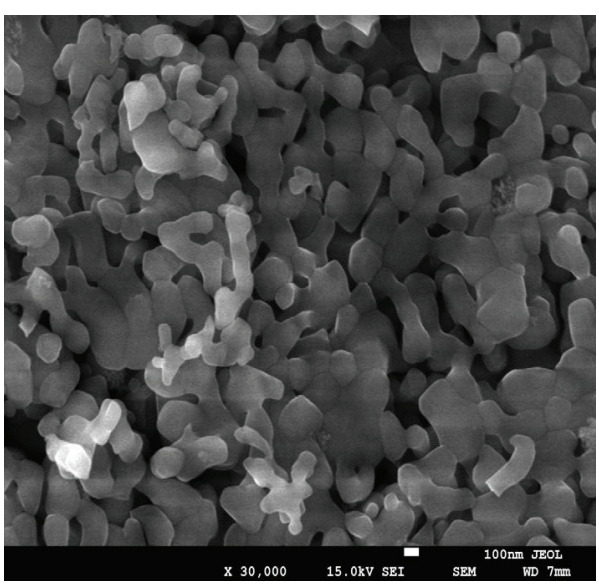

FIgURE 8: SEM image of 0.3 mole ratio La-loaded on $\mathrm{TiO}_{2} / \mathrm{Al}_{2} \mathrm{O}_{3}$.

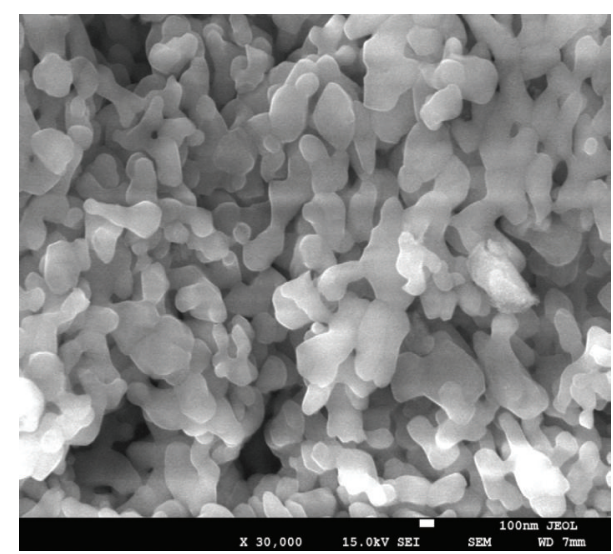

Figure 9: SEM image of 0.05 mole ratio Ce-loaded on $\mathrm{TiO}_{2} / \mathrm{Al}_{2} \mathrm{O}_{3}$.

3.1.4. EDX Analysis of Samples. Table 5 provides the experimental EDX analysis of some selected samples compared to the theoretical wt.\% of same samples.

Tables 5-7 present the data analysis for all investigated samples obtained by calculating the theoretical and the actual wt.\% loading, in addition to determining the excess 


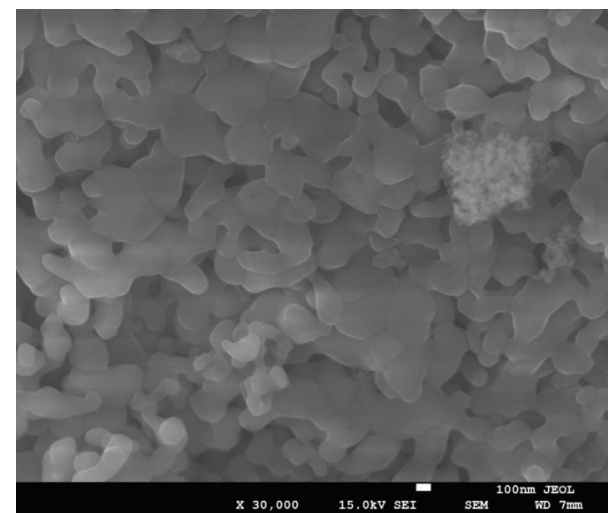

FIgURE 10: SEM image of 0.3 mole ratio Ce-loaded on $\mathrm{TiO}_{2} / \mathrm{Al}_{2} \mathrm{O}_{3}$.

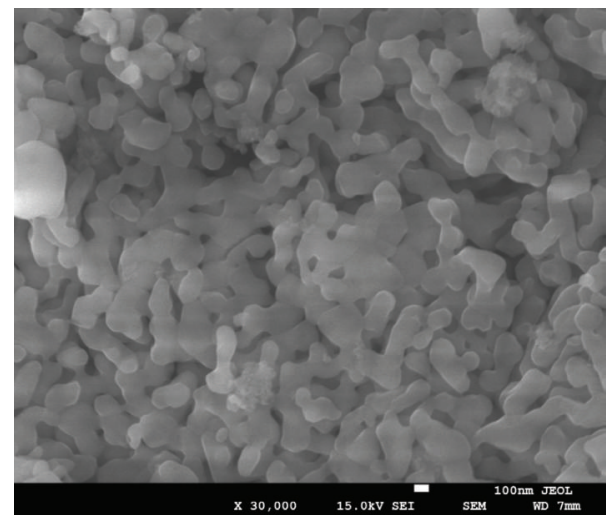

Figure 11: SEM image of $5 \mathrm{wt}$. $\% \mathrm{TiO}_{2} / \mathrm{Al}_{2} \mathrm{O}_{3}$ (using TIP as a source of $\mathrm{TiO}_{2}$ ).

TABLE 5: EDX analysis of selected samples.

\begin{tabular}{lcccc}
\hline wt.\% & $\mathrm{Al}_{2} \mathrm{O}_{3} \%$ & $\mathrm{TiO}_{2} \%$ & $\mathrm{La}_{2} \mathrm{O}_{3} \%$ & $\mathrm{CeO}_{2} \%$ \\
\hline $\mathrm{La} / \mathrm{TIP}(0.05)$ & 99.21061 & 0.789391 & 0 & 0 \\
$\mathrm{La} / \mathrm{TIP}(0.3)$ & 98.41669 & 1.583311 & 0 & 0 \\
$\mathrm{Ce} / \mathrm{TIP}(0.05)$ & 98.98106 & 1.018944 & 0 & 0 \\
$\mathrm{Ce} / \mathrm{TIP}(0.3)$ & 98.18298 & 0 & 0 & 1.817018 \\
$\mathrm{Ce} / \mathrm{TIP}(0.3)$ & 97.56178 & 0 & 0 & 2.438221 \\
$\mathrm{Ce} / \mathrm{TIP}(0.3)$ & 99.25471 & 0.745288 & 0 & 0 \\
$\mathrm{Ce} / \mathrm{TIP}(0.3)$ & 87.76509 & 0 & 0 & 12.23491 \\
TIP/Al $\mathrm{O}_{3}(5 \%)$ & 97.57552 & 2.424481 & 0 & 0 \\
\hline
\end{tabular}

surface concentration of each component. The excess surface concentration is defined as follows:

Excess surface concentration

$$
=\frac{(\text { wt. } \%)_{2}-(\text { wt. } \%)_{1}}{(\text { wt. } \%)_{1}} \times 100,
$$

where (wt.\%) $)_{1}$ is the theoretical weight percentage of loading and $(w t . \%)_{2}$ is the surface weight percentage of the metal oxide measured by EDX analysis [13].

From these tables it could be observed that the presence of $\mathrm{La}_{2} \mathrm{O}_{3}$, as a dopant, facilitated the diffusion of $\mathrm{TiO}_{2}$ into the alumina support, as reflected by the remarkably small amount
TABLE 6: Theoretical wt.\% of loading of different samples.

\begin{tabular}{lcccc}
\hline Theoretical (wt.\%) & $\mathrm{Al}_{2} \mathrm{O}_{3} \%$ & $\mathrm{TiO}_{2} \%$ & $\mathrm{La}_{2} \mathrm{O}_{3} \%$ & $\mathrm{CeO}_{2} \%$ \\
\hline $\mathrm{La} / \mathrm{TIP}(0.05)$ & 95 & 4.537242 & 0.462758 & 0 \\
$\mathrm{La} / \mathrm{TIP}(0.3)$ & 95 & 3.101841 & 1.898159 & 0 \\
$\mathrm{Ce} / \mathrm{TIP}(0.05)$ & 95 & 4.513598 & 0 & 0.486402 \\
$\mathrm{Ce} / \mathrm{TIP}(0.3)$ & 95 & 4.513598 & 0 & 0.486402 \\
$\mathrm{Ce} / \mathrm{TIP}(0.3)$ & 95 & 4.513598 & 0 & 0.486402 \\
$\mathrm{Ce} / \mathrm{TIP}(0.3)$ & 95 & 4.513598 & 0 & 0.486402 \\
$\mathrm{Ce} / \mathrm{TIP}(0.3)$ & 95 & 4.513598 & 0 & 0.486402 \\
$\mathrm{TIP} / \mathrm{Al}_{2} \mathrm{O}_{3}(5 \%)$ & 95 & 5 & 0 & 0 \\
\hline
\end{tabular}

TABLE 7: Excess surface concentrations of investigated samples.

\begin{tabular}{lcccc}
\hline \multirow{2}{*}{ wt.\% } & \multicolumn{4}{c}{ Surface excess concentration } \\
& $\mathrm{Al}_{2} \mathrm{O}_{3} \%$ & $\mathrm{TiO}_{2} \%$ & $\mathrm{La}_{2} \mathrm{O}_{3} \%$ & $\mathrm{CeO}_{2} \%$ \\
\hline $\mathrm{La} / \mathrm{TIP}(0.05)$ & 4.43222 & -82.602 & -100 & 0 \\
$\mathrm{La} / \mathrm{TIP}(0.3)$ & 3.596515 & -48.9558 & -100 & 0 \\
$\mathrm{Ce} / \mathrm{TIP}(0.05)$ & 4.190585 & -77.425 & -100 & -100 \\
$\mathrm{Ce} / \mathrm{TIP}(0.3)$ & 3.350508 & -100 & -100 & 273.5633 \\
$\mathrm{Ce} / \mathrm{TIP}(0.3)$ & 2.696609 & -100 & -100 & 401.2774 \\
$\mathrm{Ce} / \mathrm{TIP}(0.3)$ & 4.478644 & -83.4879 & -100 & -100 \\
$\mathrm{Ce} / \mathrm{TIP}(0.3)$ & -7.61569 & -100 & -100 & 2415.392 \\
$\mathrm{TIP} / \mathrm{Al}_{2} \mathrm{O}_{3}(5 \%)$ & 2.711073 & -51.5104 & 0 & 0 \\
\hline
\end{tabular}

of $\mathrm{TiO}_{2}$ when compared to values for the theoretical load and those observed for undoped samples. The facile diffusion of $\mathrm{TiO}_{2}$ into alumina appeared to exist even in undoped samples. It is suggested that approximately half of $\mathrm{TiO}_{2}$ diffused into undoped samples when compared to the theoretical loading values. The introduction of $\mathrm{La}_{2} \mathrm{O}_{3}$ as a dopant with a $0.05 \mathrm{Ti}$ : La mole ratio resulted in a dramatic increase (30\%) of $\mathrm{TiO}_{2}$ diffusion. From the data below, we can conclude that there are two types of active sites: one is predominantly a surface site associated with $\mathrm{TiO}_{2}$, and the other is bulk or diffused $\mathrm{TiO}_{2}$. From Figure 16, which indicates the catalytic activity of La-doped and undoped samples, we can observe that the sample with a $0.05 \mathrm{Ti}$ : La mole ratio showed the highest catalytic activity of all samples. Increasing the amount of the dopant, however, did not increase the catalytic activity but decreased it when compared to the undoped samples. This behavior could be explained when we examined the EDX data. This analysis showed that the $0.3 \mathrm{Ti}$ : La mole ratio sample reduced the amount of diffused $\mathrm{TiO}_{2}$ by approximately $30 \%$ when compared to the 0.05 sample. The direct conclusion based on the above behavior is that the diffused $\mathrm{TiO}_{2}$ catalytic active site is much higher than that of surface one. The decrease in diffusion of $\mathrm{TiO}_{2}$ observed upon increasing the amount of dopant may be understood as a competition between the affinity of $\mathrm{TiO}_{2}$ for $\mathrm{La}_{2} \mathrm{O}_{3}$ and that for alumina. This competition could be further influenced by the intermolecular interactions between molecules of $\mathrm{La}_{2} \mathrm{O}_{3}$, which could be favored at high levels of dopant ( 0.3 mole ratio).

This possible interaction was not observed with XRD, due to the detection limit; however, it is well observed from FT-IR spectra in Figure 6. 


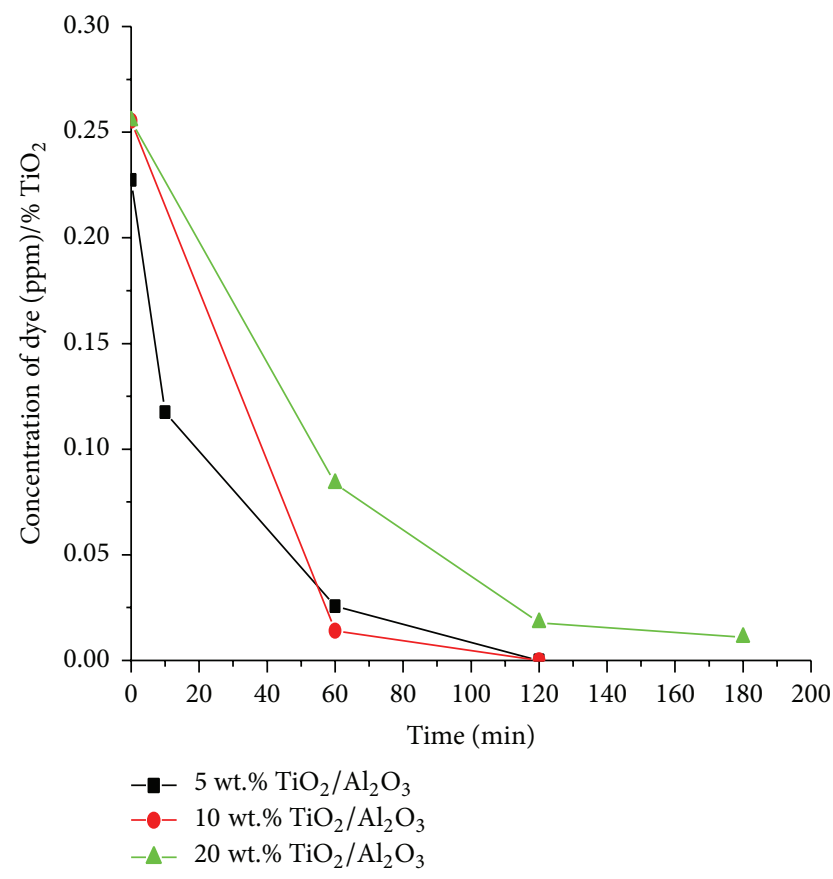

FIgURE 12: Curve of dye concentration (MO) divided by $\% \mathrm{TiO}_{2} /$ $\mathrm{Al}_{2} \mathrm{O}_{3}$ (using TIP as a source of $\mathrm{TiO}_{2}$ ) versus time during the photobreak catalytic degradation experiment.

In addition, we can discuss the observation of $\mathrm{M}-\mathrm{O}$ bands in the FT-IR spectra of doped samples (Figure 6), which could also result from the dopant facilitating the diffusion of $\mathrm{TiO}_{2}$ into alumina. Hence, the presence of multiple metal-oxygen vibrational bands in the same vicinity could be evidence of a possible interaction between them.

Returning to the $\mathrm{CeO}_{2}$-doped samples, the EDX analysis showed nearly the same enhancement of $\mathrm{TiO}_{2}$ diffusion at the low doping concentration ( 0.05 mole ratio), which was not reflected in its catalytic activity. Moreover, by increasing the dopant level ( 0.3 mole ratio) and through a different spot analysis, $\mathrm{CeO}_{2}$ seemed to aggregate on the surface. This could be explained as the affinity of $\mathrm{CeO}_{2}$ towards alumina being higher than its affinity for $\mathrm{TiO}_{2}$, which is in contrast to $\mathrm{La}_{2} \mathrm{O}_{3}$, which first interacts with $\mathrm{TiO}_{2}$.

\subsection{Effect of Precursors and Support Type on Catalytic Activity.} Figures 12-15 showed the photocatalytic activity for differently loaded samples of $\mathrm{TiO}_{2} / \mathrm{Al}_{2} \mathrm{O}_{3}$ and $\mathrm{TiO}_{2} / \mathrm{SiO}_{2}$. From these curves, we could see that the titanium isopropoxide precursor produced $\mathrm{TiO}_{2}$ evenly dispersed across the surfaces of either $\mathrm{Al}_{2} \mathrm{O}_{3}$ or $\mathrm{SiO}_{2}$ and yielded samples with high photocatalytic activity. It was also observed that the photocatalytic activity of $\mathrm{Al}_{2} \mathrm{O}_{3}$ support was much higher than that of $\mathrm{SiO}_{2}$.

For $\mathrm{Al}_{2} \mathrm{O}_{3}$ support it could be concluded that the $5 \mathrm{wt} . \%$ loading was the optimum loading with respect to catalytic activity and the decomposition rate of the organic dye.

3.3. Effect of Doping with La and Ce. Figure 16 showed the effect of different samples doped with $\mathrm{La}(0.05,0.1,0.2$, and 0.3 mole ratio), compared to undoped samples. From this figure,

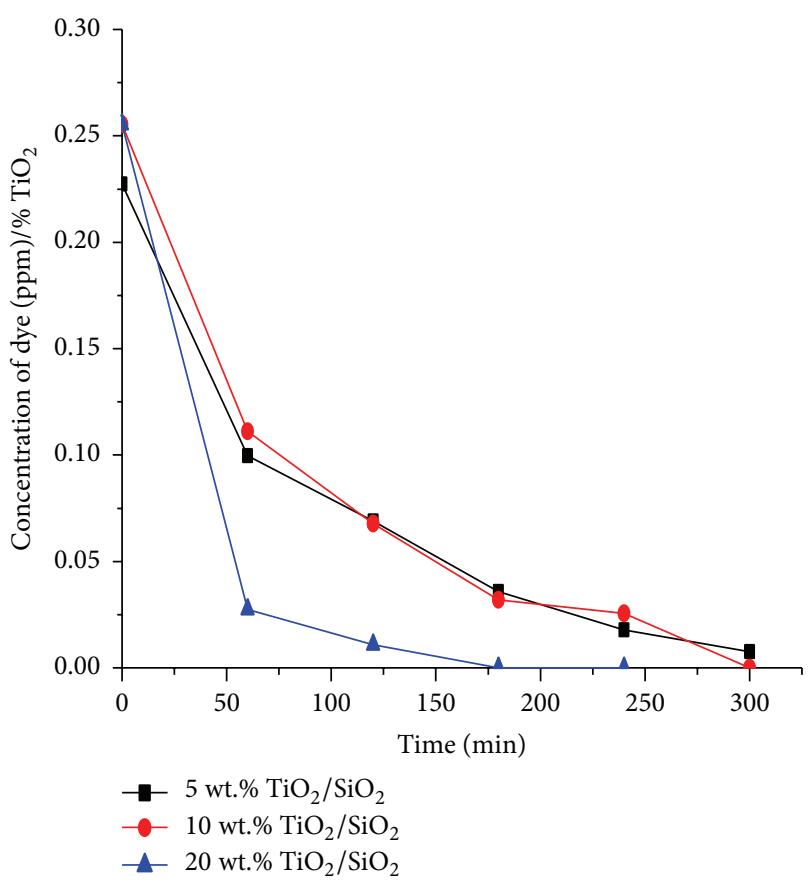

FIgure 13: Curve of dye concentration (MO) divided by $\% \mathrm{TiO}_{2} /$ $\mathrm{SiO}_{2}$ (using TIP as a source of $\mathrm{TiO}_{2}$ ) versus time during the photocatalytic degradation experiment.

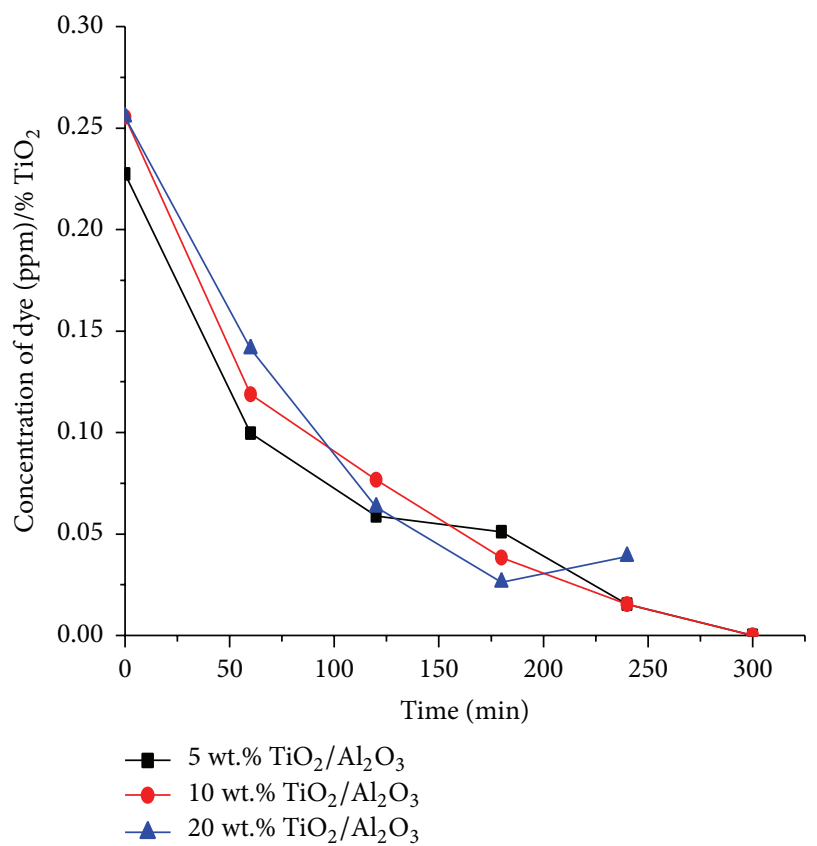

FIgure 14: Curve of dye concentration (MO) divided by $\% \mathrm{TiO}_{2} /$ $\mathrm{Al}_{2} \mathrm{O}_{3}$ (using $\mathrm{TiCl}_{4}$ as a source of $\mathrm{TiO}_{2}$ ) versus time during the photocatalytic degradation experiment.

it could be observed that as doping decreases, the catalytic activity increases. Photocatalysis reaches a maximum at a doping of 0.05 mole ratio $\mathrm{La}$, which is greater than the activity of the undoped sample. 


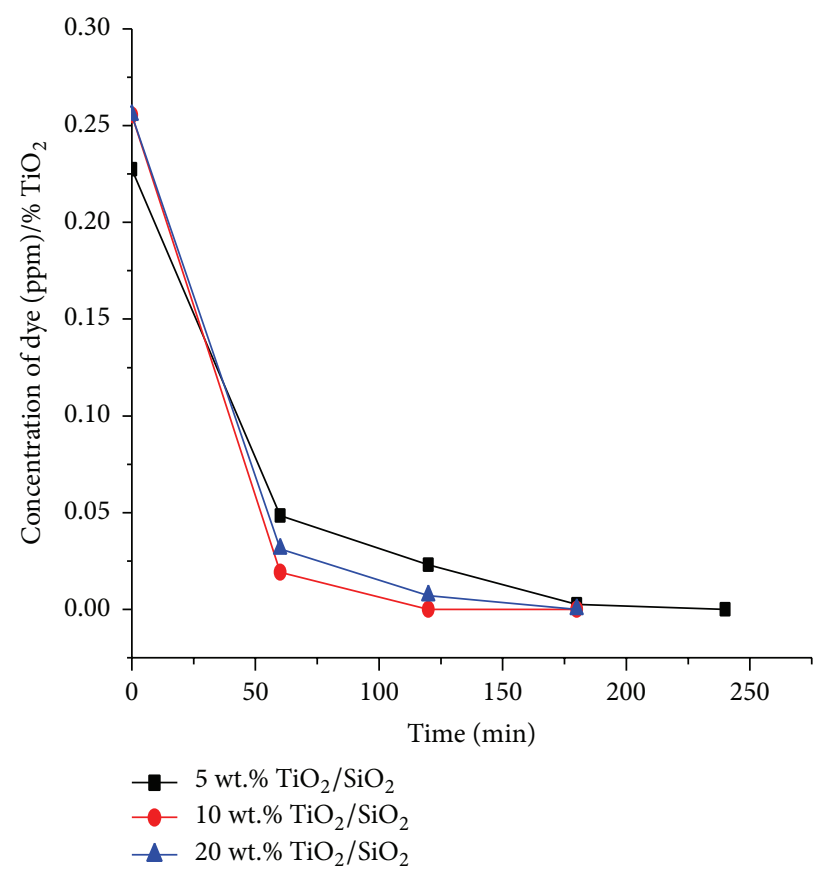

FIgURE 15: Curve of dye concentration (MO) divided by $\% \mathrm{TiO}_{2} /$ $\mathrm{SiO}_{2}$ (using $\mathrm{TiCl}_{4}$ as a source of $\mathrm{TiO}_{2}$ ) versus time during the photocatalytic degradation experiment.

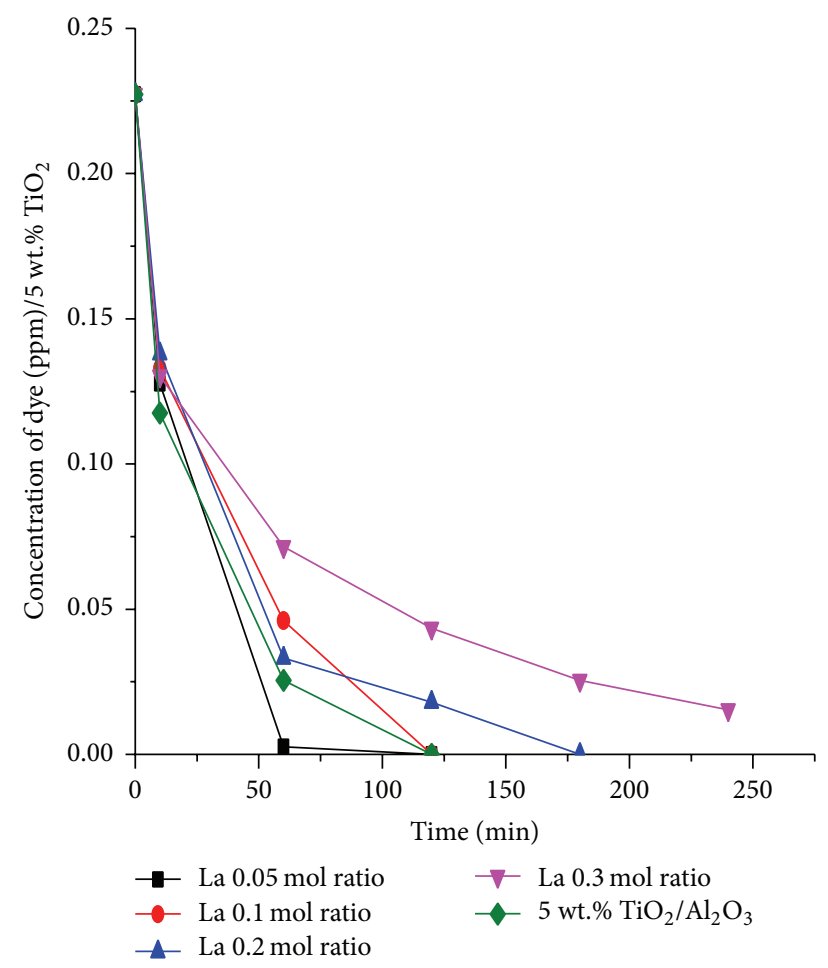

FIGURE 16: The effect of different doping levels with La 0.05, 0.1, 0.2, and 0.3 mole ratio compared to $5 \mathrm{wt} . \% \mathrm{TiO}_{2} / \mathrm{Al}_{2} \mathrm{O}_{3}$ (using TIP as a source of $\mathrm{TiO}_{2}$ ).

Moreover, Figure 17 showed the effect of different doping levels using $\mathrm{Ce}$ at the same concentrations. The same trend could be observed for Ce-doped samples as was noted for

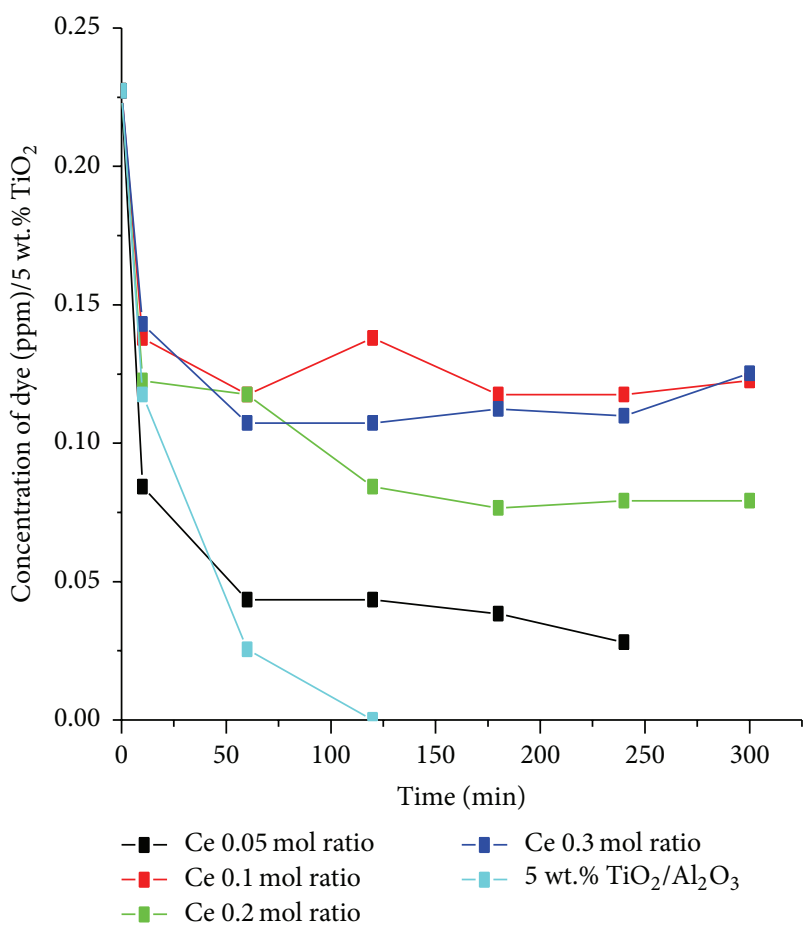

FIGURE 17: The effect of different doping levels with Ce 0.05, 0.1, 0.2, and 0.3 mole ratio compared to $5 \mathrm{wt} . \% \mathrm{TiO}_{2} / \mathrm{Al}_{2} \mathrm{O}_{3}$ (using TIP as a source of $\mathrm{TiO}_{2}$ ).

La-doped samples; however, the doping with Ce leads to a remarkable decrease in catalytic activity compared with the undoped samples.

\section{Conclusions}

From the above research, the following conclusions were drawn:

(1) Titania supported on silica or alumina could be used as a good photocatalyst for the degradation of organic dyes.

(2) Titanium isopropoxide (TIP) was found to be more effective than titanium tetrachloride $\left(\mathrm{TiCl}_{4}\right)$.

(3) The optimum loading value was found to be $5 \mathrm{wt} . \%$ $\mathrm{TiO}_{2}$ which insures its presence in nanoscale.

(4) The alumina support (corundum phase) was found to be more effective than that of amorphous silica.

(5) In trying to increase catalytic activity by dopant inclusion of either $\mathrm{La}_{2} \mathrm{O}_{3}$ or $\mathrm{CeO}_{2}$, we determined that $\mathrm{La}_{2} \mathrm{O}_{3}$ enhances the catalytic activity more than $\mathrm{CeO}_{2}$.

(6) The interactions between $\mathrm{La}_{2} \mathrm{O}_{3}, \mathrm{TiO}_{2}$, and alumina were correlated with catalytic activity.

(7) The 0.05 mole ratio for the dopant was found to be the optimum value, above which the catalytic activity decreased. 


\section{Competing Interests}

The authors declare that they have no competing interests.

\section{Acknowledgments}

This project was funded by the Deanship of Scientific Research (DSR), King Abdulaziz University, Jeddah, under Grant no. 387-247-1436G. The authors, therefore, acknowledge with thanks DSR technical and financial support.

\section{References}

[1] M. J. R. G. R. Pires, M. I. A. Ferra, and A. M. M. Marques, "Ionization of methyl orange in aqueous sodium chloride solutions," Journal of Chemical Thermodynamics, vol. 53, pp. 9399, 2012.

[2] M. Zeng, "Influence of $\mathrm{TiO}_{2}$ surface properties on water pollution treatment and photocatalytic activity," Bulletin of the Korean Chemical Society, vol. 34, no. 3, pp. 953-956, 2013.

[3] N. Daneshvar, M. J. Hejazi, B. Rangarangy, and A. R. Khataee, "Photocatalytic degradation of an organophosphorus pesticide phosalone in aqueous suspensions of titanium dioxide," Journal of Environmental Science and Health. Part B, vol. 39, no. 2, pp. 285-296, 2004.

[4] A. R. Khataee, M. Zarei, and L. Moradkhannejhad, "Application of response surface methodology for optimization of azo dye removal by oxalate catalyzed photoelectro-fenton process using carbon nanotube-PTFE cathode," Desalination, vol. 258, no. 1-3, pp. 112-119, 2010.

[5] M. Azami, M. Bahram, S. Nouri, and A. Naseri, "A central composite design for the optimization of the removal of the azo dye, Methyl Orange, from waste water using the Fenton reaction," Journal of the Serbian Chemical Society, vol. 77, no. 2, pp. 235-246, 2012.

[6] C. Girginov, P. Stefchev, P. Vitanov, and H. Dikov, "Silver doped $\mathrm{TiO}_{2}$ photocatalyst for methyl orange degradation," Journal of Engineering Science and Technology Review, vol. 5, no. 4, pp. 1417, 2012.

[7] S. Liu and K. Li, "Preparation $\mathrm{TiO}_{2} / \mathrm{Al}_{2} \mathrm{O}_{3}$ composite hollow fibre membranes," Journal of Membrane Science, vol. 218, no. 1-2, pp. 269-277, 2003.

[8] A. Adamczyk and E. Długoń, "The FTIR studies of gels and thin films of $\mathrm{Al}_{2} \mathrm{O}_{3}-\mathrm{TiO}_{2}$ and $\mathrm{Al}_{2} \mathrm{O}_{3}-\mathrm{TiO}_{2}-\mathrm{SiO}_{2}$ systems," Spectrochimica Acta Part A: Molecular and Biomolecular Spectroscopy, vol. 89, pp. 11-17, 2012.

[9] O. Zuas and N. Hamim, "Synthesis, characterization and properties of $\mathrm{CeO}_{2}$-doped $\mathrm{TiO}_{2}$ composite nanocrystals," Medziagotyra, vol. 19, no. 4, pp. 443-447, 2013.

[10] H. Guo, J. Chen, W. Weng, Z. Zheng, and D. Wang, "Adsorption behavior of Congo red from aqueous solution on $\mathrm{La}_{2} \mathrm{O}_{3}$ doped $\mathrm{TiO}_{2}$ nanotubes," Journal of Industrial and Engineering Chemistry, vol. 20, no. 5, pp. 3081-3088, 2014.

[11] T. Dascalescu, L. Todan, A. Rusu et al., "Nanosized $\mathrm{Al}_{2} \mathrm{O}_{3}$ $\mathrm{TiO}_{2}$ oxide powder with enhanced porosity obtained by sol-gel method," Revue Roumaine de Chimie, vol. 59, no. 2, pp. 125-134, 2014.

[12] B. Tajik, A. Abbassi, M. Saffar-Avval, and M. A. Najafabadi, "Ultrasonic properties of suspensions of $\mathrm{TiO}_{2}$ and $\mathrm{Al}_{2} \mathrm{O}_{3}$ nanoparticles in water," Powder Technology, vol. 217, pp. 171-176, 2012.
[13] S. A. Kosa, I. H. A. E. Maksod, L. Alkhateeb, and E. Z. Hegazy, "Preparation and surface characterization of $\mathrm{CuO}$ and $\mathrm{Fe}_{2} \mathrm{O}_{3}$ catalyst," Applied Surface Science, vol. 258, no. 19, pp. 7617-7624, 2012. 

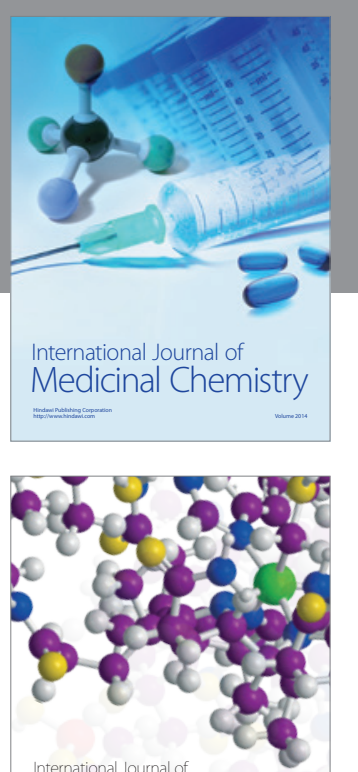

Carbohydrate Chemistry

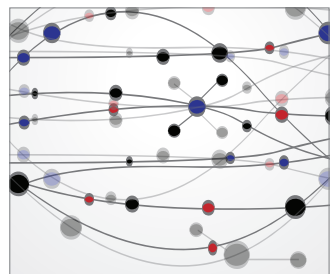

The Scientific World Journal
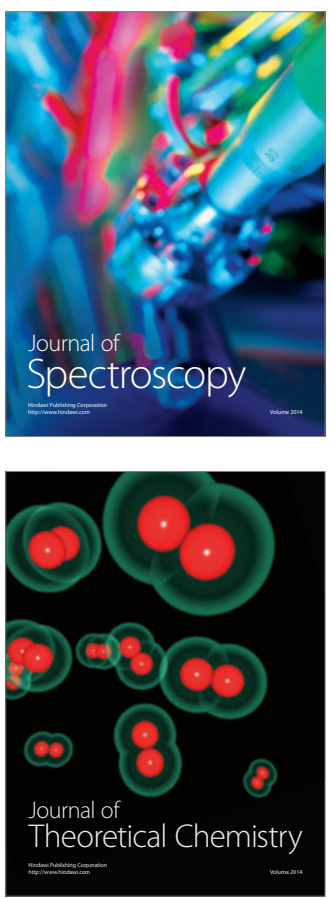
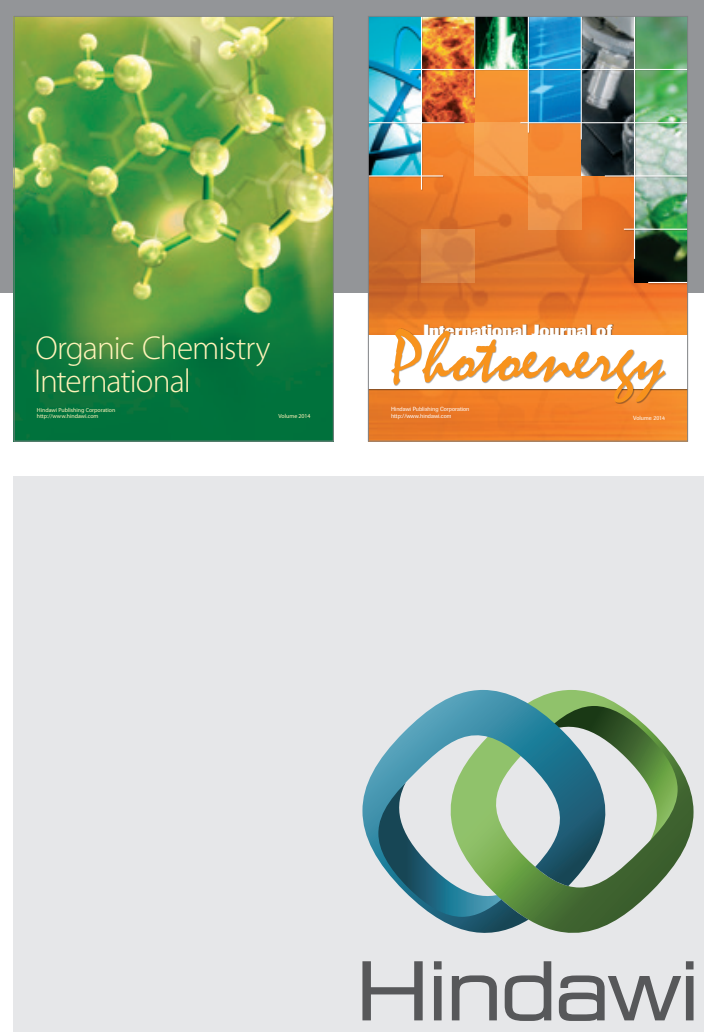

Submit your manuscripts at

http://www.hindawi.com

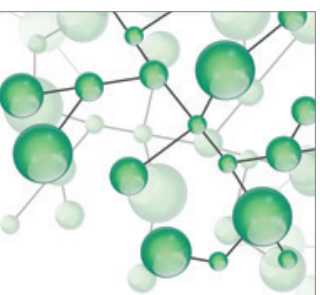

International Journal of

Inorganic Chemistry

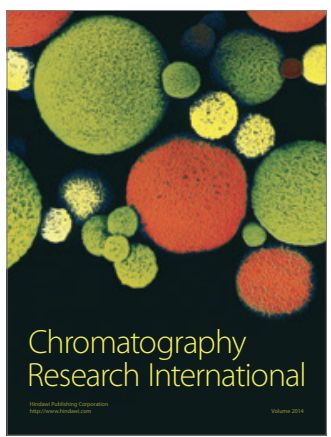

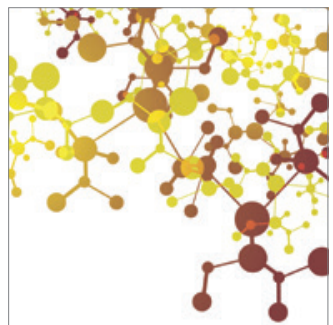

Applied Chemistry
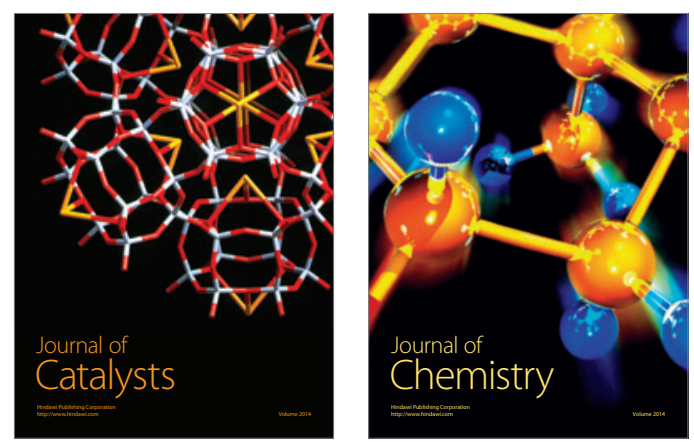
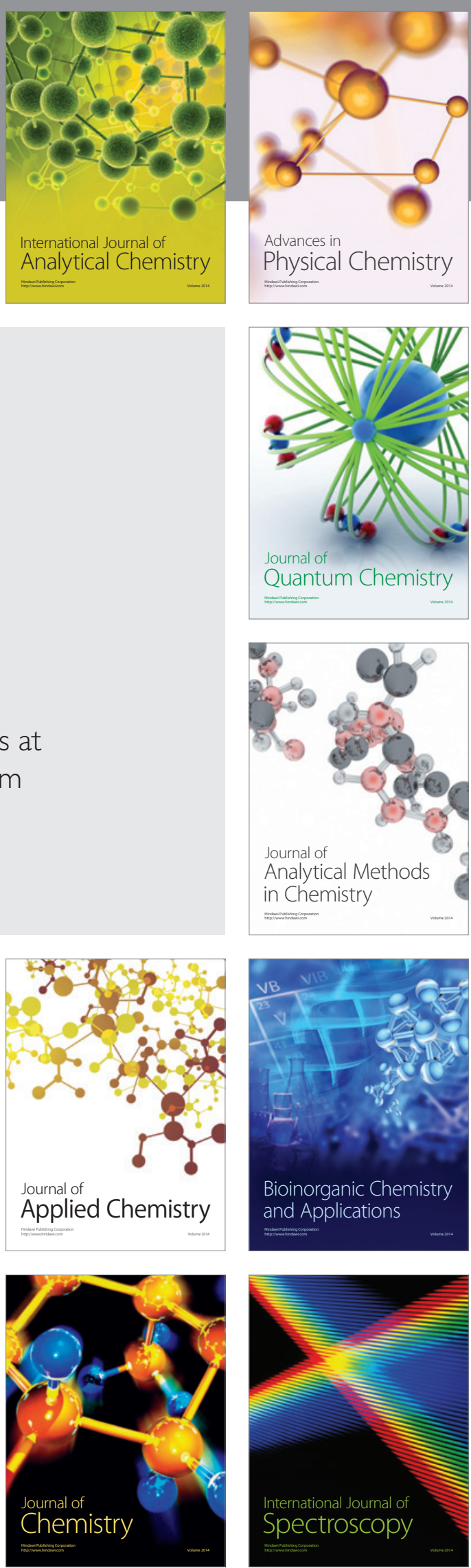